\title{
Tanzimat Romanının Karakteristiği ve Kültürel Bocalamanın İki Aktörü: Felâtun Bey ve Bihruz Bey*
}

\section{Characteristics of the Tanzimat Novel and Two Actors of Cultural Ambivalence: Felâtun Bey and Bihruz Bey}

\author{
Bahtiyar Aslan ${ }^{1 \odot}$
}

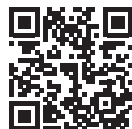

"Bu makale yazarın; Cumhuriyet Dönemi Roman Kahramanlarında Kültürel Bocalama adli doktora tezinden üretilmiștir.

'Dr. Öğretim Üyesi, Bandırma On Yedi Eylül Üniversitesi, İnsan ve Toplum Bilimleri Fakültesi, Türk Dili ve Edebiyatı Bölümü, Balıkesir, Türkiye

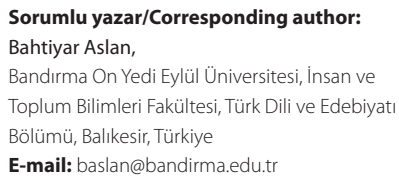

Geliş tarihi/Date of receipt: 08.11.2018 Kabul tarihi/Date of acceptance: 19.11.2018

\section{Atıf/Citation:}

Aslan, B. (2018). Tanzimat romanının karakteristiğ ve kültürel bocalamanın iki aktörü: Felâtun Bey ve Bihruz Bey. TUDED 58(2), 229-245. https://doi.org/10.26650/TUDED494448

\section{ÖZET}

Tanzimat Dönemi, Osmanlı Devletinin yüzünü Batı́ya döndüğü, dolayısıyla yüz yıllardır "öteki" olarak tanımladığı bir dünyaya öykünmeye başladığı dönemin adıdır. Bu öykünmenin doğru anlaşılması, Batııılaşmanın epistemolojik ve ideolojik temellerinin de doğru anlaşılmasına bağlıdır. Bu bağlamda, Batılılaşmayı konu edinen dönem romanlarının da aynı kriterler göz önünde bulundurularak değerlendirilmesi, genelde Türk edebiyatının Batılılaşma serüveninin, özelde de Türk romanının doğuş macerasının doğru anlaşılmasına katkı sağlayacaktır. Ahmet Mithat Efendi'nin Felâtun Bey ile Râkım Efendi romanının kahramanlarından Felâtun Bey ve Recaizade Mahmut Ekrem'in Araba Sevdası romanının kahramanı Bihruz Bey, dönemin psikolojik, ideolojik ve epistemolojik durumunu yansıtan iki kahramandır. Her iki kahraman da öteden beri yanlış Batııılaşmanın temsilcisi olarak ele alınır. Ancak iki kahraman da aynı zamanda yanlış Doğuludurlar. Felâtun Bey ve Bihruz Bey'in en karakteristik özelliği bu iki kültür ve medeniyet dairesinden birine ait olamamalarıdır. Bu gerçeğin arka planında aslında Tanzimat dönemi aydınlarının yaşadığı düalite/ikilem yatmaktadır. Osmanlı kültür ve medeniyet dünyasına doğmak, ötesi bu kültür ve medeniyet dünyasının içinde büyümek ama sonunda kendisinin karşıtı olan bir dünyanın değerlerini benimsemek zorunda kalmak ya da bunu tercih etmek gibi bir durum vardır. Yaptığımız bu çalışmada, söz konusu iki kahramanın yaşadığı kültürel bocalama/düalite dönemin epistemolojik ve psikolojik şartları göz önünde bulundurularak irdelenecektir.

Anahtar Kelimeler: Tanzimat dönemi romanı, Alafranga züppelik, Batılılaşma, Felâtun Bey, Bihruz Bey

\section{ABSTRACT}

During the period called Tanzimat, the Ottoman Empire turned its face to the West and began to emulate a world that it had defined as "the other" for hundreds of years. The correct understanding of this emulation depends on an accurate understanding of the epistemological and ideological background of westernization. In this context, evaluating period novels as the product of westernization will contribute to understanding the westernization adventure of Turkish literature in general, and in particular, the advent of the Turkish novel. Felâtun Bey, the protagonist of Ahmet Mithat Efendi's Felâtun Bey ile Râkım Efendi, and Bihruz Bey, the protagonist of Recaizade Mahmut Ekrem's Araba Sevdası, are two heroes who reflect the psychological, ideological, and epistemological status of the period. Both heroes are treated as representatives of false westernization. 
The most characteristic feature of Felâtun Bey and Bihruz Bey is that they cannot belong to both Turkish and western culture and civilization circles. Behind this fact lies the duality/dilemma of the Tanzimat-era intellectuals. This is the experience of being born into the world of Ottoman culture and civilization. In this study, we will examine the epistemological and psychological conditions of the period in which the two heroes live.

Keywords: Tanzimat period novel, Alafranga dandy, westernization, Felâtun Bey, Bihruz

\section{EXTENDED ABSTRACT}

The novels of the Tanzimat period are among the main sources for understanding how Turkish modernization is initially reflected in life and literature. The period novels are also important in terms of understanding the ideological, psychological, and epistemological conditions of their authors. Understanding the attitudes of the writers of the Tanzimat period will contribute to the evaluation of the literature of the period. In addition, it is important to correctly determine the conditions of the Tanzimat period. In Turkish novels, the West is not the genre of thriving through a similar process. There are westernization efforts behind the entry of this genre into our literature. Accordingly, our first novels are not entirely the result of a social reality but are created entirely by imitation. It is important to keep in mind that translations play an important role in the rise of the Turkish novel. Through these translations, the Turkish writer was acquiring information about the genre, in a way beginning to take steps toward becoming a novelist while the Turkish reader was introduced to the novel and grew up as a reader. Therefore, it is certain that these translations determined the direction and frame of the first Turkish novels.

Two important writers of the Tanzimat novel, Ahmet Mithat Efendi and Recaizade Mahmut Ekrem, depicted westernization as a main problem in their works. Ahmet Mithat Efendi created the character Felâtun Bey in the novel Felâtun Bey ile Râkım Efendi, and Recaizade Mahmut Ekrem used the character Bihruz Bey to discuss westernization in Araba Sevdası. In both novels, the heroes, who are the representatives of false westernization, that is, the alafranga dandyism, are often described by the authors using negative adjectives. It is true that neither writer has witnessed the pressures of social life, the ideology, epistemology, and psychology of the period. The main shortcoming of both writers' attitudes toward the heroes of the novels is that Felattun Bey and Bihruz Bey are not only flawed westernized characters but also flawed Oriental characters. This is due to the fact that in the process of westernization, society and the individuals are tied to their own cultural resources. The ideological attitudes of the writers of this period are quite sophisticated. Tanzimat intellectuals also have a share in the birth of the type of protagonists represented by Felâtun Bey and Bihruz Bey. Therefore, western dandyism is a natural consequence of the ideological, epistemological, and psychological environment that the state's apparatuses and intellectuals have prepared together. 
As we can see in the examples of Felâtun Bey and Bihruz Bey, the protagonists criticized in the novels of this period have some common characteristics. The members of this type of group are rich, spendthrift, lazy, and wannabe. They try to speak French and claim to know the language but they cannot speak it properly. They do not read books but they always keep a book with them and they have the appearance of readers. They have completely misunderstood westernization. Their perceptions and inferences are superficial and their mental development is not directly proportional to their age. In fact, they are extremely naive. The members of this type of group live superficially in the East-West duality. They do not have enough hardware for the values of two civilizations. However, this is understandable given the conditions of the period.

In spite of all this, the two novels we have mentioned are important in that they are the first works in which the alafranga dandyism, negative westernization, and the East-West conflict are discussed. The heroes of the two novels are representatives of the superficial characteristics of the East-West conflict. These characteristics will gain depth depending on the culture recorded by the Turkish novels in the future. 


\section{GíRiş}

Tanzimat dönemi modernleşme teşebbüslerinin edebiyata yansımalarını, farklı edebî türler üzerinden izlemek mümkündür. Bu dönemde kaleme alınan romanlar, bir taraftan Batılılaşma hamlelerini gösterime sunan özellikleri, bir taraftan da yerliliği yansıtan tarafları ile hem biçimsel, hem de içerik bakımından "arada kalmışlığın" göstergeleri olmuşlardır. Cemil Meriç roman için; “... bu edebî tür, bir buhranın, bir uyuşmazlığın, reelle ideal arasındaki bir nispetsizliğin çocuğu. İçtimai bir sıhhatsizlik, hiç değilse, bir tedirginlik alâmeti. Sınıf kavgaları ile sahneye çıkışı bundan. İnanmış bir toplumda, pürüzlerini yok etmiş bir toplumda, hayalî çözüm yolları aramaya ihtiyaç duymayan bir toplumda romanın ne işi var?"(Meriç, 1998, s. 287-288) der. Bu değerlendirme, Türk romanının doğuşunun Tanzimat yıllarına denk gelmesinin bir tesadüf olmadığını net bir şekilde ortaya koymaktadır. Bu bağlamda Cemil Meriç'in hükümlerinin aynen Tanzimat için de geçerli olduğunu söylemek mümkündür. Gerçekten de Tanzimat, bir buhranın, bir uyuşmazlığın, reelle ideal arasındaki nispetsizliğin çocuğudur ve ortada içtimaî bir sıhhatsizlik, hiç değilse bir tedirginlik olmasa Tanzimat'a ihtiyaç duyulmayacaktır. Bu noktada Türk romanı ve Tanzimat'ı doğuran şartların Batı'daki anlamıla -sınıf kavgası dışta tutulursa- aynı oluşuna şaşmamak gerek. Buna rağmen Berna Moran'ın da dediği gibi; bizde roman, Batı'da olduğu gibi feodaliteden kapitalizme geçiş döneminde burjuva sınıfının doğuşu ve bireyciliğin gelişimi sırasında tarihsel, toplumsal ve ekonomik koşulların etkisi altında yavaş yavaş gelişen bir anlatı türü olarak ortaya çıkmamıştır (Moran, 1994, s. 9). Burada üzerinde durulması gereken şey, kapitalizm ve modernizmin aynı bilincin ürünü olduklarıdır. Her ikisinde de insanla eşya arasındaki ilişkinin yeniden ve aynı yönde düzenlenmesi söz konusudur. Dolayısıyla Berna Moran'ın tespiti doğru olmakla beraber eksiktir. Tanzimat'ın bir modernleşme projesi ve girişimi olduğu gerçeğini göz önünde bulundurursak hiç değilse kapitalizmi doğuran bilince benzer bir bilincin varlığından söz etmek mümkün olabilir. Öte yandan her ne kadar bizde roman, Batı'dan yapılan tercümeler ve taklitlerle başlasa da, Türk aydını ve okuyucusunun, Tanzimat döneminde roman öncesi anlatılarla tatmin olduğu sonucu da çıkarılmamalıdır. Klasik Türk şiirinde öteden beri baş gösteren çözülme ve gözden düşme, anlatı geleneği çerçevesinde düşünülürse, mesnevînin gündemden düşmeye başlaması da, Türk aydınının geleneksel anlatılarla tatmin olmayan bir psikoloji içine girdiğini göstermesi bakımından manidardır. Dolayısıyla, geleneksel anlatı türleri ya hayattan çekilecek ya da ister istemez başka bir türe evirilecekti. Batı'dan roman türünün alınması bu noktalar göz önünde bulundurulduğunda daha anlamlı bir hâl alacaktır.

Batı'da ortaya çıkış kıstasları esas alındığında, romanın Türkiye'de doğuşunun doğal bir süreçten sonra gerçekleşmediği söylenebilir. Toplumumuzun romanla tanışması, Batı'da gerçekleştiği gibi kapitalizmin yükselişi, burjuva sınıfının oluşması ve ferdiyetçiliğin gelişmesiyle alâkalı bir durum değildir. Romanın ortaya çıkışı gerçekten de Batı́nın burjuvalaşmasıyla paralel gelişen bir hadisedir ve Jale Parla'nın deyimiyle yeni bir ideolojinin (liberalizmin) ve yeni bir epistemolojinin (ampirik pozitivizmin) temel ilkelerini 
yansıtır (Parla, 2006, s. 9). Ancak bir türün oluşumunun toplumsal ve tarihsel şartlarının başka, o türü tanımanın başka bir şey olduğunu unutmamak gerekir. Bu tür bir yargı, toplumumuzun roman türüyle tanışması için toplumsal ve tarihsel birtakım aşamalardan geçmesi gerektiğine işaret ediyor. Bu gerçeği dikkatimizden uzak tutmayarak Türk romanının Batılılaşmanın ve değişen şartların bir sonucu, bir yönü olarak Şemsettin Sami, Nâmık Kemal, Ahmet Mithat gibi yazarların eliyle çeviriler ve taklitlerle başladığı gerçeğini tekrarlayalım (Moran, 1994, s. 9). Batılı anlamda roman ve hikâyelerin ortaya çıkmasından hemen önce klasik edebiyat anlayışından modern anlayışa geçişin izlerini bünyelerinde taşıyan bazı ara dönem eserlerinin de kaleme alındığını unutmamak gerekir. Emin Nihat Bey'in Müsameretnâme'si, Muhayyelât-ı Aziz Efendi ve Ermeni harfleriyle basılmış bazı hikâyeler bunlar arasındadır (Enginün, 2006). Bu eserler, bizde Batılı anlamda romanın birden ortaya çıkmadığını, az da olsa bir geçiş, bir hazırlık döneminin yaşandığını göstermesi bakımından önemlidir.

Türk romanının ortaya çıkış sürecinde çevirilerin de önemli bir rolü olduğunu gözden uzak tutmamak gerekir. Bu çeviriler vasıtasıyla bir yandan Türk yazarı tür hakkında bilgi ediniyor, bir bakıma romancı olma yolunda adımlar atmaya başlıyor, bir yandan da Türk okuyucusu romanla tanışıyor ve okuyucu olarak yetişiyordu. Dolayısıyla ilk Türk romanlarının istikametini ve çerçevesini bu tercümelerin belirleyeceği muhakkaktır. Böyle olmakla birlikte ilk romanlarımızda klasik anlatı geleneğimizin çeşitli yönlerden etkisinin devam ettiğini görürüz. Gerek halk hikâyelerinin, gerekse de divan edebiyatı çerçevesinde yazılan manzum hikâyelerin etkisinin ilk romanlarımızda konu, anlatım biçimi ve üslûpta etkisini sürdürdüğünü görürüz. Robert P. Finn'in deyişiyle; Illk Türkçe romanlar, Fransız örneklerinden yola çıksalar da hem şekil, hem gelişme açısından Yakındoğu hikâye geleneği ile klasik Osmanlı şiirinin, yani divan geleneğinin zengin entelektüel içeriğinden kaynaklanan birtakım örnekleri de barındırırlar (Finn, 1984, s. 9). Bunun böyle olmasının izahı değişik birçok açıdan yapılabilir elbette. Ancak Osmanlı aydınının zihinsel ikiliğini göstermesi bakımından da ayrıca bir önem taşır ve bu durum son derece doğal kabul edilmelidir. Öte yandan, romancının muhatabı olan kitlenin de belli alışkanlıklarının olduğunu, bu alışkanlıklardan bir anda kurtulmanın mümkün olmadığını da unutmamak gerekir.

Tanzimat romancısının temel problemlerinden biri de okurun eğitimi problemidir. Tanzimat romancısının, okurunu eğitirken, onun anlatı alışkanlığını radikal bir biçimde ortadan kaldırması mümkün değildi. Geleneksel anlatım biçimlerinin önemi bu noktada bir kat daha artmaktadır. Tanzimat romancısı, okurunu başka bir dünyanın anlayışını, duyuşunu yansıtan Batılı romanın dünyasına çekebilmek için bir ara yol bulmak zorundaydı. Bu yolu da şekillendiren yine kitlelerin kültürel ve edebî birikimi olacaktır. Romancının muhatap kitlesini halk ve divan edebiyatı geleneğine bağlı, birikimlerini bu iki geleneğin nispeten farklı kuralları içinde edinmiş iki ayrı kitle oluşturmaktadır. Dolayısıyla okura ulaşmanın ya da okuru yeni türe çekmenin yolu, bu iki birikimin de Batılı romanla bir arada yorumlanmasıdır. 
Ahmet Mithat, Şemsettin Sami ve Namık Kemal gibi roman türünde eser veren ilk yazarlarımızın, roman ve geleneksel anlatı türleriyle ilgili görüşleri, Tanzimat aydınının psikolojisinin hatta epistemolojisinin belirlenmesi açısından önemlidir. Berna Moran'ın da işaret ettiği gibi Şemsettin Sami, "Şiir ve Edebiyattaki Teceddüd-i Âhirimiz" adlı yazısında geleneksel anlatılarımızı kaba ve çocukça şeyler olarak niteler. Aynı yazıda Batı ile Doğu'nun çeşitli açılardan karşılaştırıldığını görürüz. Medeniyet açısından Batılıların çok gerisinde olduğumuzu, kendimize has bir yol tutmaya muhtaç olmadığımızı, herkesin gittiği yol ortadayken başka yol aramaya lüzum olamadığını söyledikten sonra Şemsettin Sami şöyle devam eder:

“íçimizde ümem-i garbîyenin elsine ve ahvâline vâkıf olmayan bazı adamlar onların vapurlarını, demiryollarını, telgraflarını ve masnûâtlarını ve sair maddî ve zâhirî eserlerini görerek, yalnız sanayi'de kemallerini teslim ederlerse de ulûm ve maarifte ve hele şiirde, edebiyatta, tarihte, mantıkta, sarf ve nahiv ve maânîde bizim ka'bımıza varmaktan çok geri ve dûn bir mertebede bulunduklarına mutekiddirler ve bu zehâb-ı bâtıllarını tashîh etmeğe de rıza ve arzuları olmayıp, bu fikirlerinde o kadar mutmain görünürler ki kendilerine her ne kadar aksi edille ve âsâr gösterilse, yine inanmazlar ve bildiklerinden caymazlar" (Sami, 1994, s. 321).

Şemsettin Sami, medeniyetin tek yönlü bir olgu olmadığını, tekniğin bunun sadece bir tarafı olduğunu vurgulayarak, meseleye sadece teknik açıdan yaklaşanları eleştirir ve sosyal ilimler ve eğitim alanında da Batılıların bizden çok üstün olduklarını iddia eder. Yazının devamında ise Batılı yazar ve şairlerin eserleriyle bizim geleneksel anlayışımızı karşılaştırır. Şemsettin Sami'nin söz konusu yazısı, Tanzimat aydınının Batı karşısındaki psikolojisini ortaya koyması bakımından önemlidir. Bu yazının arka planında büyük bir yenilgi psikolojisinin yattığı ve bu yazının sahibinin karşısındakine nazaran daha aşağı bir seviyeden konuştuğu açıktır. Bu psikoloji, hâkim bir psikolojidir ve Tanzimat aydınından Meşrutiyet ve Cumhuriyet aydınına hatta günümüz aydınına kadar sirayet etmiştir.

Namık Kemal de romanla ilgili düşüncelerini kaleme alırken geleneksel anlatı türlerine temas eder ve onlarla ilgili görüşlerini sergiler. Romanın yeniliğine vurgu yaptıktan sonra eski eserlerimiz arasında ibret-nümâ, Muhayyelât ve Aslı ile Kerem, Ferhad ile Şîrîn gibi birtakım hikâyelerin olduğunu söyler ve romanın kendine göre tarifini verir:"...romandan maksad güzerân etmemişse bile güzerânı imkân dâhilinde olan bir vak'ayı ahlâk ve âdât ve hissiyât ve ihtimâlâta müteallik her türlü tafsilâtıyla berâber tasvîr etmektir"(Yetiş, 1989, s. 347). Namık Kemal'in roman için yaptığı tarifin öncesinde; Fakat kitabhâne-i âdâbımızda mevcud olan birkaç tercümeden anlaşılacağı vechile demesi bu tarifin kaynağının da Batı'dan yapılan tercümeler olduğunu gösteriyor. Bu tariften sonra eski şiirimize yaklaşım tarzını geleneksel anlatılarımıza da uygular ve hikâyelerimizin olağanüstülük özelliğinden hareketle şiddetli bir eleştiri getirir: 
"Halbuki bizim hikâyeler tılsım ile define bulmak, bir yerde denize batıp sonra müellifin hokkasından çıkmak, âh ile yanmak, külünk ile dağ yarmak gibi bütün bütün tabî'at ve hakîkatin hâricinde birer mevzu'a müstenid ve sûret-i tasvîr-i ahlâk ve tafsîl-i âdât ve teşrîh-i hissiyât gibi şerâit-i âdâbın kâffesinden mahrûm olduğu için roman değil koca karı masalı nev'indendir" (Yetiş, 1989, 347-348).

Bu eleştiriye hâkim olan bilincin, tabiatı ve gerçekliği öne alan bir bilinç olduğu açıktır. Bu bilincin, Namık Kemal'in "kocakarı masalı" dediği anlatıların yaratılmasına, yaşatılmasına ve aktarılmasına aracılık eden bilinçle çok farklı olduğu da ortadadır. Bu bile Tanzimat aydınının içine düştüğü ikilemi ortaya koymak için yeterli bir örnektir. Çünkü Renan Müdafaanâmesi ile İslâmiyet'i savunan bir bilincin aynı zamanda İslâm medeniyeti dairesinde teşekkül etmiş olan edebî eserlere ve bu medeniyetin edebiyat anlayışına bu kadar şiddetli saldırmasının başka türlü izahı mümkün görülmemektedir. Her iki yazarın da gerçekliğe, inandırıılığa vurgu yaptıklarını görüyoruz. Bunun, dünyayı yeni bir algılama ve yorumlama şekli olduğu açıktır. Osmanlı aydını artık dünyaya gerçekliğin -tarifini kendi medeniyetinin ötekisi olan bir medeniyetin yaptığı- penceresinden bakacaktır. Bu bakış açısına uymayan şeyleri şiddetle reddedecek ve aşağılayacaktır. Osmanlı aydını kendi içinde bir zihniyet devrimi gerçekleştirmektedir. Her devrim gibi bu devrim de sancılı olacak, birtakım travmalar yaratacak; yerleşmesi, içselleştirilmesi zaman alacaktır.

Tanzimat Fermanı, Batılılaşmanın devlet eliyle tescili anlamına geliyor ve bu yöndeki girişimlere meşruluk kazandırıyordu. Fermanın ilanıyla birlikte o güne kadar Osmanlı için "yabancılık" ve "düşmanlık" kavramlarını içinde barındıran hatta "kâfir" olarak nitelenen, dolayısıyla "öteki" konumunda olan bir kültür ve medeniyete doğru bir yönelişin gerekliliği açık açık itiraf ediliyordu. Üstelik bu, varoluşu sürekli kılmak için yapılıyordu. Diğer bir deyişle, törensel bir yenileşme görüntüsünün arkasında uğursuz bir yenilmişlik ve yabancılaşma duygusu yatıyordu (Parla, 2006, s. 10). Tanzimat'ın amacının ne olduğunu Jale Parla, Şinasi'ye yaptığı bir atıfla şöyle açıklar: "Şinasi'nin deyişiyle Asya'nın akl-ı pirânesi ile Avrupa'nın bikr-i fikrini izdivaç ettirmek" olduğuna göre; Asya'nın erkek, Avrupa'nın kadın olarak şahıslandııılığı bu evlilik eğretilemesinde egemen olan, Doğu'nun mutlakçı düşünce sistemidir. Jale Parla yazısııın devamında Namık Kemal'den de bir örnek vererek Tanzimat yazarlarının Batııış̧mayı erkek egemen bir evlilik birleşmesinin edilgin öğesi olarak gördüklerini söyler (Parla, 2006, s. 17). Bu tespitten de anlaşıldığı gibi, Tanzimat yazar ve aydınlarının zihninde eşitlikçi bir Batılılaşmanın olmadığı açıktır. Böyle bir yaklaşıma sahip bir ruhun çatışma düşüncesini kendi içinde barındırdığı da muhakkaktır. Dolayısıyla ilk dönem Türk romanlarının temel meselesini Batılılaşmanın, Doğu-Batı çatışmasının oluşturması kaçınılmazdır. Batılılaşmanın doğrudan romanın dünyamıza giriş sebebi olması da bu durumu kaçınılmaz kılmaktadır.

Ahmet Hamdi Tanpınar'ın da dediği gibi bu dönem yazarlarımız romancı muhayyilesiyle doğmuş yazarlar değillerdi (Finn, 1984, s. 17). Buna toplumsal şartların 
romanın gelişmesine uygun olmamasını, ortada bir roman hatta ciddi bir nesir geleneğinin bulunmamasını da eklersek, dönem yazarlarının kahraman yaratma konusunda neden yetersiz kaldıklarının izahı daha kolay olur. Bunun yanı sıra da dinî ve ahlâkî anlayışın ifşayı yasak eden yaptırımlarını da burada zikretmekte fayda vardır. Dolayısıyla dönem romanlarında Tanzimat'ın, Batılılaşma sorununun insanlar üzerinde yarattığı kültürel ve ahlâkî bunalımın, parçalanışın, kopuşun, yabancılaşmanın tam olarak yansıııldığından bahsetmek mümkün görünmüyor. Bu dönem romanlarında karakter yaratma hususunda ciddi teknik problemler olmakla beraber, bu çatışmayı yansıtma noktasında büsbütün başarısız saymak da doğru değildir. Ancak kendi şartları ve imkânları içerisinde dönemin ruhunu yansıtan birtakım kahramanlardan söz etmek mümkündür.

Ahmet Hamdi Tanpınar, Tanzimat sonrası devirden söz ederken, bu devrin bir özelliğinin de memlekette gittikçe kuvvetini arttıran bir ikiliği doğurması ve bu ikiliğin memleketin manzara ve ruh bütünlüğünü kırması olduğunu belirtir. Bugün bile halk dilinde ve hatta fikir hayatında o zamanlardan kalan "alafranga" ve "alaturka" (mûsikîde olduğu gibi), "eski" ve "yeni" (zihniyet meselelerinde) tabiriyle ifade edilen bu ikilik realitesinin Tanzimat'ın en büyük fatalitesi olduğunu öne sürer (Tanpınar, 1988, s. 136). Tanpınar'ın bahsettiği ikilik, en genel anlamıla Doğu-Batı ikiliğidir. Yukarıda örnek olarak verilen ikiliklerden alafranga ve yeni, Batı'yl; alaturka ve eski, doğrudan Doğu'yu çağrıştırmaktadır. Tanzimat'tan günümüze kadar sosyal hayatın bütün alanlarında farklı ölçülerde de olsa kesintisiz bir biçimde varlığını hissettiren bu ikilik, doğal olarak ilk andan itibaren edebiyatı da etkisi altına almıştır.

Türkçede ilk romanın yazııışı Batılılaşmanın resmî olarak kabulü anlamına gelen Tanzimat'ın ilanından otuz küsur sene sonra, 1872'dedir. Bir edebî tür olarak romanın, doğuşunun Batı'da burjuvalaşmayla eş zamanlı olduğuna, yeni bir ideolojinin (liberalizmin) ve yeni bir epistemolojinin (ampirik pozitivizmin) temel ilkelerini yansıttığına (Parla, 2006, s. 9) yukarıda değinmiştik. Burada üzerinde durulması gereken iki kavramdan biri olan liberalizm; devlet, toplum ve birey arasındaki tüm ilişkilerde bireyin hak ve özgürlüklerini öne çıkaran; her bireyin vicdan, inanç ve düşünce özgürlüğünün tanınması gerektiğini savunan (Güçlü, Uzun, Uzun ve Yolsal, 2003, s. 890) bir öğretidir. Ampirik pozitivizm ise; "her türden bilgi araştırmasının kayıtsız koşulsuz olgulara ya da gerçeklere dayandırılması gerektiğini savunan; bilgi edinme sürecinde yalnızca olgular dünyasını, onun temelini oluşturan deneye açık yasaları esas alan; kurgusal metafiziğin açıklamalarının ilkece doğrulanıp sınamaya açık olmadıklarından ötürü anlamsız olduklarını ileri süren; deneyle denetlenemeyen soruları sözde sorular olarak niteleyen; yanıtı sorunun kendisinde içerilmeyen soruları gerçek soru olarak görmeyerek bütün metafizik soruları dışlayan..." (Güçlü ve ark., 2003, s. 1060-1061) felsefe anlayışıdır. Liberalizm ve ampirik pozitivizmin ilkelerine dikkat edecek olursak, her iki öğretinin de sekülarizasyona hizmet ettiğini görebiliriz. Bu noktada Tanpınar'ın bahsettiği ikiliğin dönemin aydınları açııından epistemolojik bir ikilik özelliği de taşıdığı söylenebilir. Tanzimat dönemi romancısı, yazarken bir yandan içinde büyüdüğü anlatı geleneğinin pozitivist olmayan ilkeleriyle, bir 
yandan da Batılılaşmanın, çağdaşlaşmanın bir gereği olarak gördükleri romanın seküler ilkeleriyle kuşatılmış durumdaydı. Sosyal hayatın bütün alanlarına sirayet eden bu ikiliği Daryush Shayegan bir Doğulu düşünür olarak şu şekilde ifade eder;

“Düşünce ustalarım öteki dünyada daha çok mevcut olabilmek için bu dünyadan çekilmemi öğütlerken, modern ustalarım, aksine, deneyle doğrulanmayan hiçbir şeyi kabul etmememi, dogmacı a priori'lerden ve arzularını gerçeklik zanneden düşlerden kendimi sakınmamı öğütlerler" (Shayegan, 2002).

Shayegan'ın "düşünce ustalarım" dediği ustaların, Doğu’nun hikmet söyleyen mutasavvıfları olduğunu öğütlediklerinden çıkarabilmek mümkündür. Türk aydınının gerek Tanzimat döneminde, gerekse de günümüzde içinde bulunduğu epistemik bunalım Shayegan'ın ifade ettiği durumla benzerlik arz etmektedir. Bir farkla ki, Tanzimat aydınları içinde bulundukları durumun Shayegan kadar farkında değillerdir. Jale Parla konuya dair; “Tanzimat'ın Osmanlı kültürel yaşamında Doğu ve Batı normları arasında bir ikilem yarattığına ilişkin yaygın bir kanı giderek klişeleşti ve Tanzimat kültürünü 'ikilemli bir kültür' olarak damgaladı. Oysa böyle bir ikilem var gibi görünse de, Beşir Fuad'a kadar Tanzimat yazarlarının bu tür bir ikilemden ciddi biçimde etkilendiklerini, hatta ikilemin kutupları arasında gidip geldiklerini bile söyleyecek durumda değiliz" (Parla, 2006, s. 9) der ve Orhan Okay'ın "mülemma" tespitinin daha geçerli olduğunu ileri sürer. Kanaatimizce Okay'ın yaptığı "mülemma” tespiti bu ikilemin varlığını zayıflatmaktan çok kuvvetlendiren bir tespittir.' Mülemmanın sözlük anlamı, renk renk, alacalı demektir. Edebiyatta, Türkçe, Arapça ve Farsça mısralardan oluşan şiirlere mülemma denirdi. Daha çok gazel nazım şeklinde kullanılan mülemmada beytin bir mısraı Türkçe ise diğeri Arapça ya da Farsçadır. Üç dilin birden kullanılmasına çok az tesadüf edilmiştir (Pala, 2002, s. 352). Görüldüğü gibi, mülemmada dilin ya da renklerin iç içe girmesi, kaynaşıp yeni bir bütün oluşturması söz konusu değildir. Ancak renkler ya da mısralar farklı ve yan yana/alt altadır. Okay, iki kültürün aynı bünyede olmalarına rağmen, iç içe girip yeni bir bütün oluşturmadan devam ettiklerine vurgu yapıyor. Okay'ın da vurguladığı gibi bir sentezden söz etmek mümkün değildir. Şu halde, iki renk aynı bünyede de olsa kendi özelliklerini sürdürmektedir. Tanzimat aydını bu iki rengin birine (Osmanlı kültürüne ve Osmanlı́nın ait olduğu medeniyete) organik olarak bir bağ ile, diğerine ise (Batı kültür ve medeniyetine) yenilik iştiyakıyla bağlıdır. Bunun bir anlamı da iki kültür dairesine tam olarak bağlanamamaktır. Dolayısıyla dönemin aydınlarının, mülemmayı oluşturan iki rengin birleştiği/ayrıldığı çizgide durduklarını -bilinçli ya da bilinçsiz- söylemek daha doğru olacaktır. Bu da Parla'nın ikilemle ilgili tereddüdünün geçerliğini azaltmaktadır.

1 Okay'ın konuyla ilgili tespiti şu şekildedir: "Tanzimat devrinin hususiyetlerinden biri de Doğu ve Batı medeniyetinin, âdetlerinin, kültürlerinin birbirine karışmasıdır. Buna bir sentezden ziyade eski tabiriyle mülemma demek daha yakışır. Bir kültür unsurunu benimsemek değil, sadece beğenmek, eskiden de vazgeçememek, fakat bir terkibe ulaşamamak. İşte Tanzimat'ın mülemması budur." Bkz. Orhan Okay, Batı Medeniyeti Karşısında Ahmed Mithat Efendi, Millî Eğitim Bakanlığı Yayınları, İstanbul 1991, s. 343. 
Tanzimat aydınının zihinsel dünyasındaki bu ikilemin eserlerine yansıması kaçınılmazdır. Türk romanının ilk döneminin temel karakteristiklerinden birini de bu ikilik teşkil eder.

\section{Kültürel Bocalamanın Edebiyattaki İlk Aktörleri: Felâtun ile Bihruz}

Batılılaşma meselesine bir tip etrafında temas eden ilk eser Felâtun Bey Ile Râkım Efendi'dir. Eserin kahramanlarından Felâtun Bey, genel olarak alafranga züppe tipinin prototipi olarak kabul edilir. Bununla birlikte "Felâtun, Tanzimat kuşağının, yönetime ya da topluma herhangi katkıda bulunmadan, sürekli genişleyen bürokrasinin saflarında kendine yer bulmuş, ölçülü bir serveti olup iyi bağlantılar kurmuş genç adamlarının tipleştirilmiş halidir" (Evin, 2004, s. 111). Ahmet Mithat Efendi'nin adıyla özdeşleşen roman, iki zıt karakterin Batılılaşma anlayışını ele alan, onların şahsiyetleri ve yaşadıkları olaylar etrafında doğru ve yanlış Batılılaşmayı göstermeye; doğru Batılılaşmanın yollarını gösterip öğretmeye çalışan bir eserdir. Eser, "Felâtun Bey'i tanır mısınız?" sorusuyla başlar. Böylece, daha eserin girişinde Ahmet Mithat'ın romancılığının özelliklerinden biriyle karşılaşmış oluruz. Felâtun Bey, Tophane'de oturan Mustafa Merakî Efendi'nin oğludur. Mustafa Merakî Efendi, Merakî lâkabını her şeye "merakımdır" dediği için almıştır. Mustafa Merakî'nin karısı, kızını (Mihriban) doğururken ölmüştür. Mustafa Efendi, Üsküdar'daki evinden Beyoğlu'na taşınır ve alafranga bir hayat yaşamaya başlar. Ancak yüzeysel bir yaşayıştır bu. Çocuklarını da kendisi gibi yetiştirir, onların da kendisi gibi her modayı takip eden tipler olmasına zemin hazırlar. Ancak onların eğitimiyle yeteri kadar ilgilenmez. Felâtun Bey bir ara kaleme girer fakat düzenli bir şekilde devam etmediği için oradan da bir şey öğrenemez. Babasından kalan mirası har vurup harman saçarak harcamakta, gününü gün etmekle meşgul olmaktadır. Doğru dürüst bir meslek sahibi olamayan Felâtun Bey, günlerini çeşitli eğlence ve dinlencelere taksim etmiştir; Cuma ve pazar günleri seyir yerlerine gider, bunları takip eden günlerde dinlenir. Salı günü ziyaretlere tahsis edilmiştir, çarşambaları ise kaleme uğrar. Ancak kalemde daha çok diğer günler neler yaptığını anlatmakla vakit geçirir. Kız kardeşi de ondan pek farklı değildir. Mihriban Hanım, her şeyi hazır alan, el işi yapmayı bilmeyen, serbest bir kızdır.

Râkım Efendi ise Tophane'de kavaslık yapan bir babanın oğludur ve babasını daha bir yaşında iken kaybetmiştir. Râkım Efendi, Salıpazarı'ndaki üç odalı bir evde annesi ve Fedayi adlı bir Arap cariye tarafından büyütülür. Fedayi evlere hizmetçiliğe giderek, annesi ise oya yaparak, dikiş dikerek evin geçimini sağlar. Bu iki kadın, Râkım’ okutacak parayı bu şekilde kazanır. Râkım, Rüştiye'yi bitirdikten sonra Hariciye Kalemine kâtip olarak girer. Yirmi yaşına geldiğinde artık kültürlü ve birkaç yabancı dil bilen bir delikanlıdır. Bir yandan Türkçe dersi verip, bir yandan da Fransızca öğrenen Râkım, vaktini işte ve kitaplar arasında geçirdiği için ciddi bir masrafı olmaz. Fransızcadan çevirdiği bir kitap, ona ciddi miktarda bir para kazandırır, cebi para görür ve gazetelere çeviriler yapıp yazılar yazmaya başlar. Bu arada annesini kaybeder, biriktirdiği bütün parayla Fedayi kalfaya yardımcı olacak genç bir köle kız satın alır. Canan adını verdikleri bu güzel kızı yetiştirmek ve eğitmek, Râkım’ın başlıca işleri arasına girer. Canan da sürekli öğrenmek isteğiyle yaşayan bir kızdır. Yabancı 
dil öğrenir, piyano kurslarına gider ve kısa sürede kültürlü bir hanım haline gelir. Daha sonra Râkım Efendi Canan'la evlenir.

Roman, iki zıt karakterin Batılılaşma anlayışını ele alan, onların şahsiyetleri ve yaşadıkları olaylar etrafında doğru ve yanlış Batılılaşmanın yollarını göstermeye çalışan bir eserdir. Türk romanının doğuşu veya erken dönemiyle ilgili bir çalışma yapılırken, Felâtun Bey ile Râkım Efendi'den bahsetmeden bir sonuca gitmek mümkün gözükmemektedir. Bunun sebebi, eserin "gerçek anlamda bir çığır açmış olmasıdır" (Belge, 2003, s. 110). Onun çığır açıcılık özelliği, alafranga-alaturka, Doğulu-Batılı, yerli-yabancı gibi bir ikilemi eserinin meselesi hâline getirmesinden, daha doğrusu bu ikilemi bir edebî eserde dile getirenlerin ilkleri arasında yer almasından ileri gelir. Bunun da ötesinde Ahmet Mithat Efendi bu eserinde, bu ikilemin üzerinden giderek doğru Batılılaşmanın reçetesini vermeye çalışmıştır. Yani, eserde bu ikilemelerden birinin diğerine tercih edilmesi söz konusu bile değildir. Dolayısıyla çatışmanın temelini Batılılaşmak-Doğulu kalmak denklemi değil, doğru Batılılaşmak-yanlış Batılılaşmak denklemi oluşturur. Nitekim Berna Moran, Ahmet Mithat Efendi'nin toplumsal sorunlara temas eden eserlerini sayarak bunların en ilgincinin Felâtun Bey Ille Râkım Efendi olduğunu söyler ve ilginç saymasının iki nedenini şöyle açıklar: "Birincisi, Batılılaşma sorununu alafranga züppe tipini sergileyerek ele alırken, Türk romanında uzun yıllar kullanılan bu tipi ilk işleyen roman olması... Felâtun Bey Ile Râkım Efendi'yi ilginç bulmamın ikinci nedeni, Batılılaşma sorununun Türk romanının kişilerini, kuruluşunu belirlemekte nasıl bir rol oynadığına, aşırı da olsa (daha doğrusu aşırılığından ötürü) iyi bir örnek oluşturması" (Moran, 1994, s. 38-39).

Berna Moran'ın "alafranga züppe tipi" dediği bu tip, Batılılaşmayı yanlış algılayıp yorumlayan ve uygulayan kahramanların genel adıdır (Alver, 2002, s. 252-266). Eserde yanlış Batılılaşmayı temsil eden Felâtun ise alafranga züppenin prototipidir. Dolayısıyla bir bakıma bu tip, birtakım değişikliklerle karşımıza başka eserlerde Bihruz ve Meftun olarak çıkacaktır. Berna Moran, bu tipin geçirdiği gelişimi de ilginç bulur:

“Bu tipin geçirdiği gelişim ilginçtir, çünkü Felâtun, Bihruz ve Meftun aynı kalıptan çıkmış gibi görünürlerse de, aslında farklı züppelerdir ve daha önemlisi bu tip 1920'lere kadar izlendiğinde Peyami Safa ve Yakup Kadri Karaosmanoğlu'nun romanlarındaki Batı hayranı yozlaşmış alafranga insanların Tanzimat'takilerden büsbütün farklı oldukları görülür. Böylece politik ve ekonomik koşulların değişmesi sonucu yeni bir alafranga tipin oluşumunu ve yazarların aşırı Batılılaşma sorununa yaklaşımlarının ideolojik bakımdan nasıl geliştiğini gözlemek olanağını buluruz" (Moran, 1994, s. 39).

Burada politik ve ekonomik koşulların yanı sıra Türkiye'de roman sanatının bu arada gösterdiği gelişimi de dikkate almak lazımdır. Çünkü Ahmet Mithat Efendi'nin yarattığı tipler, romanla yeni tanışan ve anlatma geleneği farklı olan bir toplumda yaratılmış tiplerdir. 
Dolayısıyla ortaoyunu ve meddah geleneğinin etkisiyle ortaya karikatürize tipler çıkmıştır. Yakup Kadri ve Peyami Safa söz konusu edildiğinde ise Türk romanının geçirdiği tecrübeler devreye girer. Bu süreç içinde Türkiye'de roman sanatının ciddi atılımlar gerçekleştirdiği unutulmamalıdır. Öte yandan aynı zaman dilimi içinde Türkçe de roman dili olma yönünde ciddi mesafeler kat etmiştir. Dolayısıyla tipin gelişiminin ilginçliğinin, biraz da bu karikatürize tipin yerini roman sanatının imkânlarının iyi kullanılmasıyla "gerçekçi" tiplerin almasından kaynaklandığı söylenebilir.

Ahmet Mithat'ın ortaya koyduğu temel karşıtlık, tembellik ve israf ile çalışkanlık ve tutumluluk arasındadır. Yazarın gözünde Batılılaşmanın beraberinde getirdiği tüketim ekonomisine kendini kaptıranlara en iyi örnek, Batılı olmayı çok şık giyinmek, Beyoğlu'nda eğlenmek ve gösteriş yapmak olarak anlayan züppe tipi olduğu için, romanda müsrif adam, aynı zamanda alafranga züppeyi temsil eden Felâtun olur" (Moran, 1994, s. 39). Felâtun Bey'in karşısında ise, konuyla ilgili yazanların hemfikir oldukları gibi Ahmet Mithat Efendi'nin "alter ego"sunu temsil eden Râkım Efendi vardır. Ahmet Mithat Efendi, her fırsatta Râkım Efendi'den yana çıkar, onu koruyup kollar, adeta ona laf söyletmez. Zira "Felâtun Bey'le Râkım Efendi'de Ahmed Midhat Efendi, karşııına idealindeki yerli, ideal Osmanlı tipi Râkım Efendi'yi çıkararak alafranga züppe Felâtun'un davranışlarını, aşırılıklarını, gülünçlüklerini ve hazin sonunu keskin hatlarla, Râkım'dan yana taraf tutan bir alaycılıkla anlatır" (Andı, 1999, s. 119). Dolayısıyla yazarın sözcülüğünü üstlenen Râkım, Batı́nın ulaşmış olduğu ilim seviyesine yükselmek için durmaksızın çalışırken bir taraftan da geçimini sağlar. Oysa romanda her türlü olumsuz davranışın taşıyıcısı durumundaki Felâtun, yarım yamalak aldığı eğitimle Batılılaşmayı yanlış anlayan bir tip olarak sürekli karikatürize edilir (Tüzer, 2014, s. 144).

Daha isimlerin sembol değerlerinden başlayan bu karşıtıkta geleneksel anlatılardan gelen düalist yapı hemen her safhada kendini ele verir. Olumsuz sıfatların hepsini üzerinde taşıyan Felâtun Bey, bir bakıma bütün yönleriyle olumlu olarak gösterilen Râkım Efendi'nin, -Murat Belge'nin deyimiyle-"ayakkabılarını parlatmak üzere kullanılan bir bez gibi yerlerde süründükten sonra cezasını görür ve her şeyini kaybeder" (Belge, 2003, s. 113). Böylece fonksiyonunu ifa etmiş olur. Onun asıl fonksiyonu doğru Batılılaşmayı belirginleştirmek için "öteki" konumunda durmaktır.

Felâtun Bey tipi her ne kadar belli bir tercihin sahibi olduğu için çalışmamız açısından önemsiz gibi görünse de, buradaki tercih edişin geri planında ciddi bir fikir ve bilgi birikimi olmadığı için bizi onun tercihinin gerçeklik derecesi üzerinde düşünmeye sevk ediyor. Dolayısıyla bu tipin altı doldurulmamış bir alafrangalıkla ilgili yaptığı bir tercihin, tercihten başka bir şey olması gerekir. Ahmet Mithat Efendi, bu tipi yaratırken âdeta onu entelektüel bilgiden hatta basit hayat bilgisinden bile mahrum bırakmıştır. Dolayısıyla onun iki kültür arasında mukayese yapacak yeteneği bile yoktur. Felâtun Bey, Râkım Efendi ile birlikte döneminin sosyal psikolojisini, iki kültür arasında tercih yapmanın bir problem olarak belirmesini ortaya koymak bakımından ve tersinden de olsa o dönem aydııını doğru 
Batılılaşma konusundaki düşüncesinin belirmesine hizmet etmesinden ötürü önemlidir. Ahmet Mithat Efendi, eser vasıtasıyla "hâce-i evvel" olarak doğru Batılılaşmanın formülünü vermektedir. Murat Belge konuyla ilgili şunları söyler: "Evet, onun döneminin ya da sonraki dönemlerin bilinen formülünün onun için de geçerli olduğunu söyleyebiliriz: "Garb'ın ilmini ve fennini alalım, öğrenelim; ama kendi değerlerimizden, geleneklerimizden, inançlarımızdan kopmayalım." Ahmet Mithat da -ötekiler gibi- dönüp dönüp bunu söylemiştir" (Belge, 2003, s. 113).

Felâtun, mükemmeliyet timsali olan Râkım’ın tamamen ötekisi, yani olmadığı her şeydir. Batılılaşmaya heveslidir fakat bu hevesini yarım yamalak bir Fransızcayla ve en moda giysilerle Beyoğlu'nda gezerek tatmin etmeye çalışır.

"Tembeldir; Roman boyunca çalışırken hiç görmeyiz onu. Cahildir; her şeyi birbirine karıştırır; kendi kültürünü, dilini bile doğru dürüst bilmez. Çocuktur; Râkım'ın dediği gibi, başını sonunu düşünmeden hareket ettiğinden komik durumlara düşer. Müsriftir; çok para harcar. Saftır; kendisini gerçekten sevdiğini sandığı hoppa bir Fransız aktrise tutulmuştur; Râkım’ın uyarmasına rağmen bütün servetini onun uğrunda tüketir. Hem yazar, hem roman kişileri elbirliğince horlar, alay eder, eleştirirler onu. Felâtun, Râkım'ın antitezidir. Görevi, 'ehl-i ırz, edib, mahcup, âlim, kâmil bir zat' olan Râkım'ı daha beyaz gösteren siyahı temsil etmektir" (İnci, 2005, s. 81-82).

Abdullah Uçman eserin önemini şu cümlelerle belirler:

“Görüldüğü gibi Felâtun Bey ile Râkım Efendi romanı edebiyatımızda alafranga tipi işleyen ilk eser olması bakımından ayrı bir önem taşımaktadır. Batılılaşmayı yanlış anlayan ve yanlış değerlendiren, bunları sadece giyim kuşam, eğlence ve Frenkçe kelimeler kullanmaktan ibaret gören ve böylece alafranga olduğunu zanneden bu tipin benzerleri, daha sonraki yıllarda başka romancılar tarafından da sık sık ele alınıp işlenecektir. Ahmet Mithat Efendi romanında alafranga tipin karşısına Batı kültürü ile Osmanlı kültürünü birleştirmiş ideal bir tip olan Râkım Efendi'yi çıkarmış, roman boyunca bu iki tipin birbirine zıt çeşitli vasıflarını mukayese etmek suretiyle de her iki tip hakkında okuyucuda belli bir kanaat uyandırmaya çalışmıştır" (Uçman, 2007, s. 113).

Ahmet Mithat Efendi, Râkım'ın kitabına uydurarak gerçekleştirdiği her şeyi makul karşılar. M. Fatih Andı, Râkım Efendi'nin ahlâk anlayışına dair Tanpınar'a da atıfta bulunarak şunları söyler:

"Zira Râkım Efendi hem eve aldığı cariyesini kendisine âşık ederek evlenir, hem de Buyoğlu'nda Frenk bir metresi (Jozefino'su) vardır. Evlendiği günlerde metresinden de bir çocuğu olur. Ama Ahmed Midhat Efendi, devrin alafranga âdâb-ı muâşeretinden ve Batılı "opportuniste" ahlâkından 
behreyâb olan Râkım Efendi'sinden tarafa tavır koyar, onun bu kaçamaklarını gerçek alafrangalık'ın cilvelerinden görür. Yazara göre kahramanı 'Koca Râkım'dır, 'Bizim Râkım Efendi'dir" (Andı, 1999, s. 119).

Felâtun Bey, daha romanın başından, babasının anlatıldığı kısımdan başlayarak sürekli kendisine olumsuz sıfatlar yüklenen bir roman kahramanıdır. Ahmet Mithat Efendi, Felâtun Beyin babasının Üsküdar'daki evinden, varını-yoğunu ucuz-pahalı demeden satıp savarak sırf alafranga bir hayat yaşamak için Tophane'nin Beyoğlu'na yakın bir mahallesine yerleştiğini ifade eder, yeni muhitte kurduğu hayat tarzı, kızı ve oğluyla ilgili bilgiler aktarır. Arkasından da Felâtun Bey'in babası Mustafa Merakî Efendi ile ilgili tafsilatın lüzumsuz olmadığını hatırlatır (Efendi, 2015, s. 8-9). Bütün bu tafsilat aslında; “Böyle babanın böyle oğlu olur" demek içindir. Roman boyunca çeşitli olaylar ve durumlar içinde Felâtun Bey sürekli aşağılanır, gülünç durumlara düşürülür. Yazar, Felâtun Bey'in durumunun insani ve anlaşılabilir bir durum olduğuna dair en küçük bir ihtimale bile yer bırakmaz. Öte yandan yazarın da dâhil olduğu Tanzimat aydınlarının kahir ekseriyetinin alafranga eser verme heveslerinin, Felâtun Bey ve babası Mustafa Merakî'nin psikolojileriyle örtüştüğünü de göz ardı etmemek gerekir.

Alafranga züppe tiplerinden biri de Bihruz Bey'dir. Bihruz Bey, Recaizade Mahmut Ekrem'in Araba Sevdası (1997) adlı eserinin başkahramanıdır. Eser 1896'da basılmıştır. Eserin hikâyesi son derece basittir. Amaç, dönemin İstanbul'unun Batılılaşmayla birlikte edindiği tüketim kültürünü yani savurganlığı ve tembelliği Bihruz Bey tipi vasıtasıyla gözler önüne sermektir. Eserde, Bihruz Bey'in Çamlıca Tepesi'nde yeni açılan bir mesire yerinde genç bir hanımla tanışması anlatılır. Genç hanımın adı Periveş'tir ve Bihruz Bey bu hanıma âşık olur. Bihruz Bey'in asil ve varlıklı bir ailenin kızı olarak hayal ettiği Periveş, aslında basit bir fahişedir. Bihruz, aşkından sararıp solmakta, acı çekmektedir. Sonunda Periveş'e bir mektup yazar. Bihruz Bey'in Keşfi Bey adında yalancılığıyla ünlü bir daire arkadaşı vardır. Bir gün Periveş'ten haber alamadığı için üzülen Bihruz'a onun öldüğünü söyler. Bihruz, büyük acılar içindedir ve ne yazık ki Periveş'in mezarının yerini bile bilmemektedir. Bir Ramazan akşamı Şehzadebaşı'nda dolaşırken aniden karşılaşırlar, Periveş'i önce sevgilisinin kız kardeşi zannederek yanına gider ve ona Periveş'in mezarının yerini sorar. Sonunda, gördüğü kızın Periveş olduğunu, dahası onun düşkün bir kadın olduğunu anlar. Büyük bir hayal kırıklığı ve Periveş'le yanındaki Çengi'nin hakaretleri ve gülüşmeleri arasında oradan uzaklaşır.

Romanın kahramanı yirmi üç-yirmi beş yaşlarında, bir vezir oğlu olan Bihruz Bey, yarım yamalak öğrenim görmüş bir gençtir. Vezir oğlu olması sebebiyle de dadıların, özel hocaların, uşakların ellerinde yetişmiştir. Yazları Çamlıca'da, kışları Süleymaniye'de oturan Bihruz, giyimde, gezmede modayı takip etmekte, lüks mağazalardan alışveriş etmektedir. Züppe olduğu için marka düşkünüdür. Pardösüsü, potinleri hep devrin ünlü markalarındandır. $O$ da tüketim kültürünün esiridir ve sürekli alışveriş eder. Lüzumsuz yere çiftlerce ayakkabı, düzinelerce gömlek, kravat, çorap alır. 
"Arabaya düşkünlüğü ise onun maddiyata ne kadar önem verdiğine işarettir. Hayranı olduğu Batı́nın maddi özelliklerine aşırı bir tutkunluğu vardır, Batı'nın ondaki karşılığı çoğunlukla maddi yanıdır; tüketim, giyim-kuşam ve bir de yeni adetlerin gündelik hayatındaki ağır yeri. Bu bakımdan Bihruz, tam bir Batıcı züppe tipini temsil eder. O bir uygarlık hastalığına yakalanmıştır; ait olduğu dünyaya yabancılaşmış ve hayran olduğu üstün bir uygarlığı taklide kalkışmıştır" (Alver, 2002, s. 259).

En büyük merakı ise pek zarif arabasıyla gezinti yerlerinde dolaşıp kendini göstermek, herkesten daha şık giyinmek, Türkçe cümleler arasında Fransızca sözcükler kullanmaktır. Pek anlamasa da elinde bir Fransızca gazeteyle orada burada gözükmeyi, berber, garson, terzi ve kunduracılarla Fransızca konuşmayı sever.

“Bu, insana hemen Rus toplumunu hatırlatır ve birçok nitelikleri bakımından Bihruz Bey bir Türk Oblomov'u sayılabilir. İkisinde de uygarlık hastalığının aynı çeşidi görülür: kök ve kimlik yoksunluğu. Arada başka koşutluklar da bulunabilir; tutucuların Bihruz Bey'e karşı olan tepkileri Slavofillerin Batıcılara karşı gösterdikleri tepkiyi hatırlatır. Böylece Bihruz Bey sendromu kültürler arası bir boyut kazanıyor. Bunun çerçevesini ise geleneksel kültürlerin dağılması çizer" (Mardin, 1992, s. 38).

Bihruz Bey tipi, yalnız züppeliği yönüyle eleştirilen, alay edilen bir tip değildir. Berna Moran'ın da belirttiği gibi yazar, daha çok onun özendiği bir aşk çeşidiyle alay etmektedir. "Ama bu, Batı'ya özenmenin başka bir şeklidir. Zira bu aşkın kaynağı da romantik Fransız edebiyatıdır ve Bihruz işte bu Fransız romanlarının kahramanlarına hayrandır; onlara özenmektedir" (Moran, 1994, s. 58). Bihruz Bey, Periveş'le karşılaştığı andan itibaren kafasında bir roman kurgusu belirmiştir. $\mathrm{O}$ andan itibaren kendisi de, Periveş de birer roman kahramanıdır. Bu, onun gerçeği algılamasına engel olmuştur. Dolayısıyla Bihruz Bey, en baştan beri aslında bir hayal dünyasında yaşamaktadır. "Bihruz, Namık Kemal'in Intibah'ında yerdiği, sonraları şık ve Şıpsevdi gibi romanlarda da karşımıza çıkan şımarık Osmanlı gencidir. Bu tipin ilk örneklerini meddah, Karagöz ve ortaoyunu gösterilerinde bulabiliriz" (Finn, 1984, s. 89).

Bihruz Bey de tıpkı Felâtun Bey gibi, daha romanın başlangıcından itibaren mahkûm edilir. Yazarın, "Muhteşem Bihruz Bey" (Ekrem, 1997, s. 214) ifadesinden başlayan alaycılık, ilkokulu on altı yaşında ancak bitirişini, babasının tayini esnasında tahsilinden geri kalmasın diye(!) annesiyle İstanbul'da bırakılışına, kaleme girişi, berbere gidişi, terziye elbise ısmarlayışı, süslü gezme ve Fransızca konuşma hevesine kadar devam eder. Bu bakımdan her iki yazarın kahramanlarına karşı tutumlarında bir paralellik vardır. Onlara göre Felâtun ve Bihruz Bey gibi tipler, kendi toplumlarına yabancılaşmış, Batı'yı körü körüne taklit eden, Batıdan gelen her şeye karşı sorgusuz sualsiz hayranlık duyan tiplerdir. Bu tiplerin kendi kültürleriyle bağları kopmuştur. Başka bir kültürle aralarında bir bağ oluşturmak, daha 
doğrusu o kültürün dairesi içine girmek için çabalayıp durmaktadırlar. Kültürel alt yapıları yeterli olmadığı için de, bu yeni kültürün, yaşama biçiminin unsurlarıyla doğru irtibat kurmayı başaramamaktadırlar. Bu yanlış irtibat kurmalar, yanlış algılayıp yorumlamalar sonucunda ortaya bir şahsiyetten çok bir karikatürü andıran tipler çıkmaktadır.

\section{SONUÇ}

Romanın, Türk edebiyatına girişi sancılı bir sürece tekabül eder. Illk dönem romanlarının doğru bir değerlendirmesi, bu sancılı sürecin bir yansıması olan yenilgi psikolojisinden, Batılılaşma hareketlerinin epistemolojisinden hatta ideolojisinden bağımsız yapılamaz. Dönemin en belirgin özelliği Doğu-Batı ikiliğidir. Kültürel bocalamanın ve düalitenin romandaki yansımasının, Tanzimat dönemi romanları söz konusu edildiğinde bu ikilik ve ikiliğin doğurduğu çatışma ekseninde gerçekleştiği görülmektedir. Bu çalışmada ele aldığımız Bihruz Bey ve Felâtun Bey tiplerinde de gördüğümüz gibi, bu dönem romanlarında eleştirilen kahramanların ortak özellikleri, onların zengin mirasyedi tipler olmaları, Batılılaşmayı yanlış algılamaları, zihinsel gelişimlerinin yaşlarıyla orantılı olmaması, yüzeysel yaşamaları ve Doğu ve Batı medeniyetinin değerleri hakkında yeterli bilgiye sahip olmamalarıdır. Her ikisinin de Batılılaşmayla ilgili tercihleri bilinçli değildir. Yaşadıkları durum tam bir arada kalmışlıktır. Dolayısıyla ne Felâtun, ne de Bihruz çatışmanın iki kanadından birine mensuptur. Bu tipler, Batı algıları yüzeysel olduğu için kültürel bocalama ve düaliteyi de yüzeysel yaşayan tiplerdir. Ama tek sebep bu değildir; Doğu algıları ve Doğu'ya dair bilgileri de son derece yüzeyseldir. Bunun böyle oluşunda dönem yazarlarının, devletin Batılılaşma kararını ve tutumunu desteklemelerinin ve bu süreçte toplumun ve bireylerin milli kültürleriyle bağlarının koparılmasının da payı vardır. Kısacası iki medeniyete ve iki medeniyetin epistemolojisine dair yeterli donanıma sahip değillerdir. Meseleye böyle bakıldığında alafranga züppe tipinin doğal bir sonuç olduğu söylenebilir. Ancak devrin şartları göz önüne alınırsa, bunun anlaşılabilir bir şey olduğu da söylenebilir. Çünkü devrin aydınlarının bile bu düalite karşısında çaresiz kaldıkları bir gerçektir. Dolayısıyla her iki romanda da sürekli hırpalanan bu iki tiple ilgili yazarlarının tutumunun insaf sınırları dairesinde olmadığını da söylemek mümkündür.

\section{KAYNAKÇA}

Alver, K. (2002). Züppeliğin sosyolojisi: Türk romanında züppe tipler örneği. Hece, Türk Romanı Özel Sayısı, 65-66-67, 252-266.

Andı, M. F. (1999). Roman ve Hayat, İstanbul: Kitabevi Yayınevleri.

Belge, M. (2003). Felâtun Bey İle Râkım Efendi. Kitaplık, 61, s. 110-114.

Efendi A. M. (2015). Felâtun Bey ile Râkım Efendi (İ. Keskin, Haz.). İstanbul: Türk Edebiyatı Vakfı Yayınları. Ekrem, R. M. (1997). Araba sevdası. İ. Parlatır (Ed.), Bütün eserleri III içinde (s. 205-445). İstanbul: Milli

Eğitim Bakanlığı Yayınları. 
Enginün, İ. (2006). Yeni Türk edebiyatı-Tanzimat'tan Cumhuriyet'e (1839-1923). İstanbul: Dergâh Yayınları. Evin, A. Ö. (2004). Türk romanının kökenleri ve gelişimi. İstanbul: Agora Kitaplığı.

Finn, R. P. (1984). Türk romanı (Illk dönem:1872-1900) (T. Uyar, Çev.). İstanbul: Bilgi Yayınevi.

Güçlü, A., Uzun, E., Uzun, S. ve Yolsal, Ü. H. (2003). Felsefe sözlüğ̈̈. Ankara: Bilim Sanat Yayınları.

Issı, A. C. (2002). Türk edebiyatının romanla tanışması. Hece-Türk Romanı Özel Sayısı, 65-66-67, s. 16-20. İnci, H. (2005). Felâtun Bey'i tanır mısınız? Kitaplık, 83, s. 81-85.

Mardin, Ş. (1991). Makaleler 4-Türk modernleşmesi, İstanbul: Iletişim Yayınları.

Meriç, C. (1998). Kırk ambar, rümuz-ül edeb (C. 1, M. A. Meriç, Haz.). İstanbul: Illetişim Yayınları.

Moran, B. (1994). Türk romanına eleştirel bir bakış 1, Ahmet Mithat'tan A. H. Tanpınar'a. İstanbul: İletişim Yayınları.

Okay, O. (1991). Batı medeniyeti karşısında Ahmed Mithat Efendi. İstanbul: Millî Eğitim Bakanlığı Yayınları. Pala, İ. (2002). Ansiklopedik divan şiiri sözlüğü. İstanbul: L\&M Yayınları.

Parla, J. (2006). Babalar ve oğullar Tanzimat romanının epistemolojik temelleri. İstanbul: Iletiş̧im Yayınları. Shayegan, D. (2002). Yaralı bilinç-geleneksel toplumlarda kültürel şizofreni (H. Bayrı, Çev.). İstanbul: Metis Yayınları.

Şemseddin Sami. (1994). Şiir ve edebiyattaki teceddüd-i âhirimiz. M. Kaplan, İ. Enginün, B. Emil ve Z. Kerman (Ed.), Yeni Türk edebiyatı antolojisi içinde (C. 3, s. 318-323). İstanbul: Marmara Üniversitesi Fen-Edebiyat Fakültesi Yayınları.

Tanpınar, A. H. (1988). 19'uncu asır Türk edebiyatı tarihi. İstanbul: Çağlayan Kitabevi.

Tüzer, İ. (2014). Ahmet Mithat anlatılarında kimlik inşası ve modernizm. Ankara: Akçağ Yayınları.

Uçman, A. (2007). Türk romanında ilk alafranga tip: Felâtun Bey. M. Armağan (Ed.), Ahmet Mithat Efendi Kitabı içinde (s. 105-114). İstanbul: Beykoz Belediyesi Kültür Yayınları.

Yetiş, K. (1989). Ölümünün 100. yıldönümü münasebetiyle Nâmık Kemal'in Türk dili ve edebiyatı üzerine görüşleri ve yazıları. İstanbul: İstanbul Üniversitesi Edebiyat Fakültesi Yayınları. 
